\title{
Struggle Between the Real and the Fictive: The Development of Chinese EFL Learners' Voice Construction in Short Story Writing
}

\author{
Shiying Huang ${ }^{1}$ \\ ${ }^{1}$ Faculty of English Language and Culture, Guangdong University of Foreign Studies, Guangdong, China \\ Correspondence: Shiying Huang, Faculty of English Language and Culture, Guangdong University of Foreign \\ Studies, Guangzhou, China.
}

Received: July 13, 2019 Accepted: August 5, 2019 Online Published: August 7, 2019

doi: 10.5539/elt.v12n9p22 URL: https://doi.org/10.5539/elt.v12n9p22

\begin{abstract}
The issue of voice has received considerable critical attention in second language writing (SLW) in the past decades. This study intends to enrich the research of voice in the Chinese context, which may mirror some issues in EFL environments. The short story writing process of an English-major undergraduate was particularly analyzed in this study, based on Canagarajah's (2014) analytical framework for voice analysis. After tracking the writing process for five weeks, it could be found that the student could deliver a rather satisfactory voice effect through her text, although she went through some struggle in the dialogic process. The narrative voice, the plot structure and the character were major features that the student focused on to convey her ideas. The study also provides some insights to EFL/ESL teachers about assisting students to express themselves in English writing.
\end{abstract}

Keywords: voice construction, short story writing, EFL learners, dialogic process

\section{Introduction}

In recent decades, voice in writing has been attracting considerable interest in the field of second language writing (SLW). However, scholars have paid little attention to the issue of voice in Chinese students' writing, while it has been much emphasized abroad. As the prominent theme of International Conference on Teaching and Researching EFL Writing in China (CEFLW) in 2018, the issue of voice requires the need for further research in the Chinese context. In the meantime, the research of voice in China can provide a glimpse of voice in EFL contexts for SLW researchers.

Since few studies have examined the voice in short story writing, this study attempts to fill this gap. As the dialogic view of voice has gained wide acceptance in this field (Canagarajah, 2014) and there was a call for more research in classroom contexts (Tardy, 2015), this study aimsto enrich the study of EFL learners' voice in short story writing from the dialogic perspective by drawing on Canagarajah's (2014) analytical framework for voice analysis. This research may shed some light on the writing pedagogy to assist the learners to write in a discernible voice.

\section{Literature Review}

\subsection{Definitions of Voice}

Voice is an ambiguous and slippery concept to grapple with and its definitions could be categorized into three dimensions: the individual, the social and the dialogic (Tardy, 2012a). Matsuda (2015) further classifies them into three camps: expressivists, social constructionists and social constructivists.

Generally, expressivists (Atkinson, 2001; Elbow, 1999; Jeffery, 2011) relate voice to individuality, claiming that voice is self-presentation within texts. By contrast, social constructionists contend that voice should be explored in the social context, arguing that individualized voice overlooks the multiple-facet nature of voice, where socio-economic background, profession and national culture play a part (Prior, 2001; Yancey, 1994). Instead of going into binary camps of the individual and the social, social constructivists try to find a balance between, noticing a dialogic notion of voice (Canagarajah, 2014; Dressen-Hammouda, 2014; Mastuda, 2001, 2015; Tardy, 2012a). From this perspective, voice is the result of the interaction of individual and social aspects, compared to a dialogue between the two aspects. Mastuda (2001), in favor of this view, described voice as " $\ldots$ the amalgamative effect of the use of discursive and non-discursive features that language users choose, deliberately or otherwise, from socially available yet ever-changing repertoires", indicating the sophisticated, interactional 
and dynamic process of voice construction. The dialogic view has well gained acceptance (Canagarajah, 2014) and this study aimsto investigate the construction of voice on this theoretical basis. In the study voice is defined as the amalgamation of choices made by student writers over the textual features in order to communicate their intended meanings effectively, which is personally and socially influenced as well as evolves over time in a dynamic manner.

\subsection{Voice in Texts}

\subsubsection{Voice in Genres}

A range of genres have been studied, such as academic writings (Tardy \& Matsuda, 2007, 2008; Dressen-Hamouda, 2008; Camps \& Ivanic, 2001), autobiographical genre (Canagarajah, 2014), and standardized writings (Helms-Park \& Stapleton, 2003; Yoon, 2017; Zhao, 2017, 2019). Voice in academic writings is often associated with disciplinary knowledge; voice in autobiographical genres is affected much by personal experience; as for standardized examination writings, voice is often studied with rating scales to investigate the relationship between voice and text quality. However, voice in short stories was rarely examined, which is a form of narratives that "construct a pattern of events with a problematic and/or unexpected outcome that entertains and instruct the reader or listener" (Butt, Fahey, Feez, Spinks, \& Yallop, 2003). It consists of "a class of communicative events, which conveys meanings using specific lexis and grammatical structures in a specific socio-cultural setting" (Wong \& Lim, 2014), and may lead to rich communication, negotiation and engagement of both the writer and the reader. It is worth exploring the complexity of voice in such a creative genre.

\subsubsection{Textual Features and Rating Scales of Voice}

Some researchers set out the study of voice from the angle of certain linguistics features, such as boosters, first person pronoun, hedges, attitude markers and directives (Tang \& John, 1999; Wu \& Rubin, 2000; Hyland \& Milton, 1997; Palacas, 1989; Barton, 1995). However, when researches confine voice to specific linguistic features, some content-related features of voice are neglected. Some have pointed out that linguistic features should not be overemphasized, while content-related features require much attention in the study of voice (Stapleton \& Helms-park, 2008; Stock \& Eik-Nes, 2016).

Some researchers try to capture the notion of voice through rating scales or rubrics (Helms-Park \& Stapleton, 2003; Hyland, 2008; Yoon, 2017; Zhao \& Llosa, 2008; Zhao, 2017, 2019). When rating voice with scales or rubrics according some textual features, it treats voice as a static element while neglecting the complexity and dialogic nature of voice.

No matter studying voice through particular linguistic features or with rating scales, the concept of voice becomes prescriptive, which may lead to obstacles in exploring the complexity of voice construction in depth. The concept of voice should not be equated to some concrete features. Instead, it could be indicated through these features. Since features demonstrating voice in short stories have barely been investigated, it is necessary to fill this gap, considering that many studies have explored the features in academic writings.

\subsection{The Instruction of Voice}

Voice has been attached importance to in writing classrooms for decades, but the instruction of voice is contentious as much as its definition. Elbow (1999) contends that individuality should be emphasized in composition pedagogy, which is personal voice in the text. Contrastively, Ramanathan and Atkinson (1999) disagree with conflating voice with "Western-style" individualism, which is contradictory to some other cultures. They thus underscore learners' sociocultural background in writing pedagogy. Also, from the social perspective, Dressen-Hammouda (2008) argues that instruction about disciplinary specialist knowledge and implicit cues should be included in genre-based course in order to help learners construct their disciplinary identity. The instruction of voice in these views only partially addresses voice from a single dimension, not from a dialogic perspective.

Canagarajah (2014) makes a breakthrough from the dialogic perspective in this respect, exploring the learner's voice construction within her drafts of literacy autobiography (LA) longitudinally with the implementation of negotiated pedagogy. The negotiated pedagogy comprised of writing weekly journals, input readings, writing and revising drafts of an LA, feedback from peers and the teacher, responses and interactions between, and writing final reflective essay. These exercises could prompt "students' engagement in the components (i.e. identity, role, subjectivity)" in the analytical framework that he postulated for voice analysis, through which the complexity of voice construction could be observed.

With the popularity of the dialogic view of voice, considering a dearth of studies on the instruction, more studies concerning the instruction of voice in classroom contexts are of necessity (Tardy, 2012; Canagarajah, 2014; 
Morton \& Storch, 2019).

In summary, there is a lack of studies on the construction of voice in short stories; many studies have overlooked the dynamic and complicated nature of voice when simply confining voice to particular textual features; features indicating voice in short stories need to be explored; studies on instruction of voice to assist learners' construction of voice need to be enriched. In view of these gaps and under-represented research of voice in Chinese context, this study intends to explore Chinese EFL learners' voice construction in short stories in the classroom contexts with Canagarajah's (2014) analytical framework of voice. Hopefully, it could help bridge the gaps and make some contribution to the writing pedagogy in China.

\subsection{Analytical Framework: Canagarajah's Heuristics for Voice Analysis}

This study is going to adopt Canagarajah's (2014) heuristic for voice analysis to interpret voice with four components: identity, role, subjectivity and awareness, a model developed on the basis of the dialogic view.

Canagarajah (2014) develops a heuristic for voice analysis to explore the amalgamative effects of voice of multilingual students. As demonstrated below, it is a teaching model characterized by interactions between the textual and the extra-textual, where writers and readers, influenced by "identity[ies] beyond the text", co-construct amalgamated voices in the text through continuous negotiations.

In this model, voice is composed of four components: identity, role, subjectivity and awareness. Identity is relevant to one's history such as language, ethnic, national affiliations; role refers to one's social and subject positions at schools, workplaces, professional communities or in the family, which may vary across communicative interactions; subjectivity is an ideological construct affected by different discourses, indicated through one's decisions made in genre conventions, communicative norms and value systems; awareness is the reflective process, during which language choices are strategically made with the reshaping of identity, role and subjectivity.

This model features dialogicality in that writers and readers need to negotiate different or even conflicting layers in order to "gain a measure of coherence". In this process, these layers are influenced by the writer's and the reader's four components of voice. The interaction of these components results in the construction of voice.

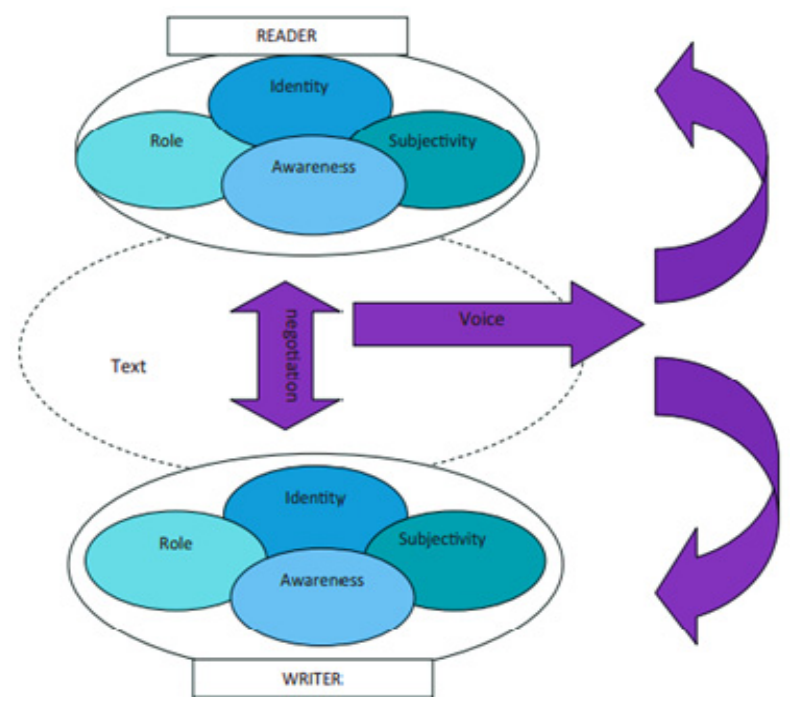

Figure1. Canagarajah's heuristics for voice analysis

During negotiations, problems such as biases, ideological and cultural conditioning may recurrently occur so that it requires ongoing negotiations in the construction of voice. The effect of voice is shaped by specific writing or pedagogical writing, or in other word, by the writing ecology.

\section{The Study}

\subsection{Research Question}

This study aims to explore Chinese EFL learners' voice construction in writing short stories with Canagarajah's (2014) analytical framework of voice analysis. Two questions were adressed: 
1) How do the components (i.e. identity, role, subjectivity, awareness) function in the negotiation for voice from the author's perspective?

2) What textual features reflect voice in the process of negotiation?

\subsection{Research Context and Participants}

The participants of the study were 76 English-major undergraduates in a university of foreign language studies in South China, but only one participant is reported in this article.

All the participants were from three parallel classes, who were attending a course titled Intermediate English Writing in their second term of freshmen year. In this course, they were required to learn and write narratives, which lasted 16 teaching weeks with one session per week. This course was co-taught by two experienced professors, one of whom taught nonfictional narrative writing for 11 weeks and the other focused on short story writing in the last five weeks. During the early 11 weeks, particular writing techniques of narrative such as foreshadowing, flashback, showing and telling were involved in the teaching. In the last five weeks, the teacher focused on skills of deceiving short stories. The former teaching provided some preparation for the later one.

Before writing the final assignment of short story, all the participants had completed 2 nonfictional narrative assignments, one movie review and one fictional story. The pedagogical cycle of short story writing followed the sequence: teacher instruction and writing a scene of conflict in the $1^{\text {st }}$ session; teacher instruction, peer review, continuing writing the story and writing reflection in the $2^{\text {nd }}$ session; teacher instruction and completing the story in the $3^{\text {rd }}$ session; teacher instruction, peer review, revising the stories and writing reflection in the $4^{\text {th }}$ session; teacher instruction, revising the stories and writing a reflexive essay in Chinese in the $5^{\text {th }}$ session. New input readings were provided for the participants fortnightly. During the five weeks, the participants have read excerpts from short stories of The Killers by Ernest Hemingway, Charles by Shirley Jackson, Waiting by Ha Jin, The Lady or the Tiger by Frank R. Stickton, The Chinese-English Dictionary for Lovers by Xiaolu Guo, and The Color Purple by Alice Walker.

After Session 3 in the short story teaching cycle, the teacher arranged teacher-student conferences for personal writing instruction based on students' requests. Among 76 participants, forty-eight had attended the conferences. Then eight students were selected for a final interview from the forty-eight students. The students selected, on the one hand, showed their willingness and activeness to speak out, or were perplexed by conveying their intentions to readers. On the other, the revisions, the reflections and their responses in the conferences indicated their complicated process of negotiation for voice, which is worth exploring in depth. However, due to limited space, only one participant was selected to discuss in this paper. The report of the other participants, who displayed diverse features in the negotiation process, requires another article.

The selected participant, called Liu, showed her struggle between nonfiction writing and fiction writing when she was required to write a fictional short story, unlike non-fictional narratives she wrote in the early stage. Her struggle between the real story and the fiction was obvious in the process of negotiation for voice. After attending her first conference, her story went through a change and made improvement. In the following two short meetings (i.e. her second conference and final interview), she showed her excitement and pride in writing her story, in contrast to her trouble and dissatisfaction at the very beginning. The complicated development of Liu's voice construction in the whole composing process will be illustrated in the finding section.

\subsection{Data Collection}

The study collected data from classroom observation, documents, conference observation and interviews.

\subsubsection{Classroom Observations}

The data collected from classroom observations were mainly about teacher instruction and classroom interaction. Three classes were observed in the five teaching weeks of short story writing. Therefore, there were fifteen classroom observations in total. Every classroom observation was audio recorded. Besides, the discussions in the process of peer review were required to be audio-recorded in groups. Additionally, the teaching materials, including input readings, textbooks and teaching slides, were collected before or after class.

\subsubsection{Documents}

Document data included short stories of different drafts and reflections.

Students' short stories of different drafts played a crucial role in the data collection, which, on the one hand, displayed students' choices and treatment of voice, and on the other hand, provided stimulus for the final interviews. Five drafts of each student's short stories were collected. Moreover, in the drafts of the teacher-student conference attendees, data of teacher feedback could be collected. 
More than that, reflections could be collected along with the second, the fourth and the fifth draft. The guiding questions for the first two reflections involved the theme of the story, the inspiration of the theme, peer feedback and the author's responses, and challenges in writing short stories. As for the final reflection in Chinese, apart from aspects included in previous reflections, were still concerned about the response to the biggest challenge, the pride of the story and the reason, and the tit-bits in the process of writing.

\subsubsection{Conference Observation}

By observing teacher-student conferences, we could learn more about students' inter- and intra-struggles in the negotiation process. In the conference, the teacher asked about the feedback from the peers and offered feedback to the student according to the questions he/she raised or the problems demonstrated in the writings. The conferences were all audio-recorded.

\subsubsection{Interviews}

Since in the data collected in previous stages we knew very little about the author's history, we decided to administer a final interview for each of the selected participants. The interview questions were tailored based on each participant's story, such as character prototype and reasons for some details in plotting. Moreover, questions about the author's character, hobbies, and experience were also included.

\subsection{Data Analysis}

To explore how components (i.e. identity, role, subjectivity, awareness) functioned in the process of negotiation for voice, data of peer-review discussions, relevant classroom interaction, reflections, conferences and interview were examined, focusing on information about the author's history, negotiation with different discourses and the reflective process. Based on the definitions reviewed previously, different information was concerned in the data analysis of the four components. To analyze identity, data revealing one's history, including character, language, writing/education/living experience, writing style or so, were focused; as to role, we considered all the participants as student writers in this writing context; in terms of subjectivity, we particularly looked at decisions and thinking during or after interaction with peers and the teacher, or influenced by some other planned discourses such as readings, news, videos and so on; with respect to awareness, reflective or commentary remarks associated with the other three components or the negotiation process were highlighted.

In order to observe what textual features reflected the authorial voice, different drafts of short stories were examined and revisions of each draft were particularly paid attention to. Meanwhile, the motif of the stories and justification for the revisions was scrutinized. With this regard, such data in reflections as theme, responses to peer feedback, challenges, pride of short stories, tit-bits in the writing, data in conferences about responses to the teacher feedback and problems the students had, and data in interview about the author's intentions of some details in the story, were analyzed.

\subsection{Findings}

Liu's short story was about two senior-school girls' communication and life, drawing inspiration from her personal experience in her senior school. The main characters in the early drafts were Xiao Yu and Xiao Yue and the prototype of Xiao Yu was Liu herself. To start with, she intended to use her story to show the importance of respecting and understanding between friends. But in the end, she tried to arouse reader's thinking about ways of living. From Draft 1 to Draft 3, her writing was more a nonfictional narrative than a fiction, although she tried to make her story fictional by telling the story in the third narrative voice and creating the fictitious names. She was aware of the problem but she was at a loss to address it. However, she made a noticeable change after attending her first teacher-student conference and eventually completed a rather decent short story compared to her drafts before. The struggle in Liu's trajectory of short story writing was much worth exploring from the perspective of voice through the four components- identity, role, subjectivity and awareness. This section will look into this problem with this regard and then identify the textual features that Liu resorted to convey her intentions.

\subsubsection{Identity}

In the negotiation for voice, Liu's identity played an essential role, featured by the life experience, language, reading experience and writing experience.

Liu's story was originated from her life experience in senior school so that she composed her writings on this basis in the whole process. At the very beginning, she was puzzled by writing a fiction based on a real story, who revealed in the conference that she couldn't help loading her emotions and feelings in the character. When the teacher asked about details of her experience in order to help her collect some material for the story, she thought it immoral to disclose her friend's privacy in her story. In the early stage of Liu's writing, as revealed in the first 
conference, most of the scenes and things in her story conformed to her real experience. After Liu got to know some skills of writing a fiction in the later drafts, she selected some common scenes in senior school but wrote what might not happen to her in the past to convey her ideas. As can be seen, her life experience was always a crucial source for her composing in this process.

Language was repeatedly emphasized by Liu in her first reflection as well as the second conference. In her first reflective essay, she expressed her trouble with delivering her meanings in English. Then in the second conference, she repeated that it was difficult to shift between Chinese and English. Later, she consulted about the method to improve her language. When it came to the influence of writing experience in the secondary school on the present story, she stated that the description or imagination of settings in Chinese was probably of some help, but it was not easy to turn it into English. As a result, according to Liu's response, language was a problem for her to communicate effectively in the negotiation process.

Liu indicated in her reflections and conferences that she had problems in writing this short story. She partly owed this to her dearth of reading. Even if she read, she noticed more the educational and logical meanings than the plots. In addition, few chances of practicing story writing but more of argumentative writing also contributed to her present writing. Logic and reasoning were accentuated in her secondary-school writing, which might partially explain her preaching and educating in the initial drafts.

Overall, such factors as life experience, language, reading and writing experience were part of Liu's history, indicating her identity and affecting much in the negotiation process. Life experience was a major source for Liu's story; difficulties of shift between two languages posed some trouble in the communication; Liu's reading and writing experience in secondary school resulted in her focus on the logic, reasoning and preaching, as reflected in her present writings to some extent.

\subsubsection{Role}

When taking up the role of student writer, Liu seemed to have some conflicts between her role and her identity. Such conflicts were obvious in her early drafts and she also expressed these struggles in her reflective essays and the conferences.

At the very beginning, Liu failed to detach her personal experience from her short story, resulting in more a non-fiction than a fiction. In the first conference, she put it:

I used omniscient narrative voice so that I could attend to both characters. But often I couldn't help attaching myself to the character.

For this reason, although Liu used the third voice to tell the story, it was more a limited voice, against her initial intention.

Additionally, Liu found the plots contradictory to her own experience. She didn't know how to write what she hadn't experienced and considered it better not to reveal others' privacy in her story. She said:

I don't know the reason. So I don't know how to write... it was not that case. How can I write that...I thought it was immoral to write the other's privacy in my story. I just learned afterwards that she lived in a single-parent family and was raised by her aunt.

As a novice story writer, Liu was perplexed by the conflict between her existing writing knowledge derived from her writing experience and the present genre knowledge learned in the course. She revealed in the second conference that most of her writing was argumentative, attaching importance to reasoning and the logic. She wrote narratives in primary school, however, in time order and she cared less about the plots. That's why she couldn't help telling the story in a "telling" manner instead of showing.

In summary, the role of student writer contradicted to some of Liu's identity features, leading to her struggle in her story writing. On the one hand, she felt difficult to write a fictional story based on her real story. On the other, she didn't know how to apply some skills different from what she learned to write before in her present story writing.

\subsubsection{Subjectivity}

Drafts of the story could reflect indirectly Liu's voice shaped by different discourses while reflections, conferences and interview provided chances to learn about Liu's subjectivity among these discourses directly.

In the $2^{\text {nd }}$ conference, Liu pointed out that the first conference played a key role in her story writing. After the conference, she altered the main idea of her short story from respecting and understanding to ways of living. The plots and scenes she revised supported and served for her ideas much better than drafts before. It could be 
observed that her revision largely followed the teacher's advice, not just in terms of plot and themes but also some detailed descriptions.

In peer review, Liu's peers posed similar problems as the teacher did to her. However, it seemed that peer feedback didn't function as much as teacher feedback. For example, from the first peer discussion for draft 1, a peer stated that Liu's story was more telling than showing, which made her story boring. Liu in her reflection responded that she didn't know how to address it but to write more, and then hopefully she would get the know-how. In the $2^{\text {nd }}$ peer discussion, another peer pointed out that she couldn't read the theme of Liu's story, and the plots and scenes seemed to be irrelevant to the theme. Liu again felt confused about it.

Apart from teacher feedback and peer feedback, we might detect Liu's subjectivity in writing skills influenced by input readings. In the second conference, Liu mentioned that she seldom used flashback due to fear of misuse. Nevertheless, in her quiz, she said flashback in the input reading Waiting inspired her to use it in her story in order to catch the reader's interest. Besides, she tried to write dialogues in similar style as those in the Killers by Hemingway, another input reading in the classroom, to create a certain mood with only a few words.

Overall, Liu showed her subjectivity among these discourses to various extents. Teacher feedback in the conferences exerted a large amount of influence to the Liu's writing process and Liu was an effective advice taker and practitioner in response. However, Liu was dull in action in face with similar questions from the peers. From input readings, Liu showed her autonomy in learning and selecting particular skills to apply in her story.

\subsubsection{Awareness}

Through Liu's reflective essays, the conferences and the final interview, it could be observed that Liu was a self-examining agent. Her awareness developed progressively and dynamically. The improvement of her story in the end reflected the effectiveness of her constant reflexive process.

At the outset, Liu was at a loss to respond to the problems pointed out by her peers. It was hard for her to detach herself from the story and she didn't know how to convey her meanings to her readers. Characters, interesting plots and language were challenges for her in her writing. She struggled to use the techniques taught in the course to write her story, but failed to deliver a piece of good work.

Then she came to the teacher for personal instruction. At the beginning of the conference, Liu couldn't even speak up her writing motif and got stuck in presenting her ideas through plots. The teacher spent much time on learning about her real story, trying to help her distinguish her writing motif. After that, they discussed the plot structure of the story in order to present the theme effectively. Learning that short story should be dramatic and unexpected, Liu seemed to get some clues about her writing. She said:

That is, I should magnify the aversion, magnify the pleasure, magnify the uneasiness in the examination, and magnify the paradox in my plots.

The revised draft proved the conference effective in that Liu story was more a fiction than a narration. Beyond that, in the second conference, she could evaluate her own story through such genre features as dialogue, thoughts, plots, characters and settings. Compared to her confusion about writing short story before, it seemed that Liu began to get the know-how to write her short story based on her personal experience with genre knowledge.

Beyond the awareness of genre knowledge in short story writing, Liu also developed her thinking toward life in the process of writing. In the final interview, Liu reported that she found what she was writing was what she was experiencing. She got clearer about her mind as she wrote. The writing enabled her to think further and deeper about her present life.

It moved beyond my senior-school life. It is also what I am experiencing. We are preparing for many final examinations these days. My classmates and roommates studied day and night in the library, but I just like to get enough sleep and then have cozy review hours in café. I didn't understand why they are so nervous, but then realized it's nothing but personal choice of life.

Writing the short story provided a connection to life for Liu, or in some way, prompted her awareness of thinking.

Influenced by her history, the role of student writer and the ideological construct shaped by different discourses, Liu moved from initial confusion to awareness of the application of genre knowledge to express her mind, and then eventually to further thinking about life through writing. 


\subsubsection{Textual Features}

One of the drastic changes in Liu's short story was the narrative voice. In her early writing, although she claimed that she used omniscient voice to attend to both characters, what displayed in the text was limited voice. Since she couldn't detach herself from the story, her writing delivered more information about Xiao Yu, the character that took herself as the prototype. After the first conference, Liu took the teacher's advice to write from Xiao Yue, the other character's perspective and she decided to write in the first person voice from Xiao Yue's eyes. She was glad about this change. She said in the second conference:

I liked this change. I like to write in "I", from my friend's perspective. I could write whatever I want to. I don't need to worry about the problem of nonfiction anymore. When I wrote in "she", it was easy to overlook somebody in my story.

It seemed that change in narrative voice allowed Liu a full play to deliver her ideas through her story. In Liu's case, it might be safe to say the narrative voice was a distinct feature that reflected Liu's voice.

Plot was crucial to convey Liu's ideas. At first, Liu intended to express the idea of respecting and understanding between friends. But the scenes she wrote only gave her readers, including her peers and the teacher, an impression of the unstable relationship between two girls. She told her readers many things that happened between these two girls, such as being desk-mates, having meals together, being good friends then and playing together more than before, one girl getting bad results in an examination, than the girl studying all the time without talking to the other girl, and then the other feeling strange but not talking to that girl either. Liu's story by far was like a journal account.

After consulting teacher for advice, Liu figured herself out that what she wanted to tell her readers was different choices in life across different people. Based on this motif, she conceived the plot structure with the teacher's help. In Liu's previous drafts, she used flashback, with an attempt to draw the reader's interest. However, in her later drafts, she was aware that flashback didn't help develop her story and quit it. Liu tried to indicate and amplify the conflicts with particular scenes. In her revised draft, "I" studied late at night in the classroom so as to show that "I" was a studyholic. After "I" returned to the dorm, "I" kept studying against the noisy roommates in the room. Then "I" unexpectedly had my noisy roommate as the deskmate. "I" wasn't so satisfactory with this until "I" was invited to her house and experienced the fun with friends. Then "I" changed. "I" became less studyholic so that "I" forgot an examination and got the worst grade that "I" had never had. I then felt struggled between having fun with friends and focusing on studying hard. Liu didn't help "I" make a choice but left suspense to the readers. Liu particularly emphasized the description and scenes of studying late in classroom, life in dorm, being deskmates, having fun in the party and struggle in the examination. Liu commented on her change in plot structure:

I feel quite satisfied with my present plots because there are twists and turns in my story now, unlike the flat story before.

Additionally, Liu considered that the character "I" was the most satisfactory in her story. She thought the character she created was real because the experience of "I" echoed a wide range of people in real life, including Liu herself. To build up this character, she no more used plenty of dialogue to develop her story. Instead, she invested more thinking to "I" and showed the character through actions and descriptions in details. For example, when "I" left classroom late at night, Liu used detailed description of setting and "my" thinking to show "I" was a diligent girl; in the dorm, while "I" was studying, the girls were noisy in contrast and "my" thinking reflected my dissatisfaction with them. By developing a round character "I", Liu delivered her own ideas to her readers with the character's eye. Liu indicated in her reflection:

I am most proud of my character. I can clearly see her change. As her life change from being study-only to being colorful, her attitude toward life also made a change. She was used to being alone and studying always, but then she was attracted by colorful life. Seeing the failure of the examination, she felt really regretful. Then she was caught in a dilemma of choosing between colorful life and concentration on study. The character, dialogue and detailed description indicated both changes. The character "I" became more vivid, real and round.

\section{Discussion}

The purpose of this study is to investigate Chinese EFL learners' voice construction in short stories writing in order to fill the research gap of voice in short stories and meanwhile to enrich the research of voice in classroom contexts.

By examining the EFL learner Liu's short stories writing process, it could be found that the narrative voice, the plot structure and the characters were major features that the writer utilized to convey her voice. With 
Canagarajah's (2014) analytical framework, the complexity of Liu's voice construction could be observed, interpreted with the four components (i.e. identity, role, subjectivity and awareness) from the writer's perspective. The findings in these respects were closely related and they will be discussed in this section.

Studies in the literature evaluated voice with particular textual features by using rating scales (Helms-Park \& Stapleton, 2003; Hyland, 2008; Yoon, 2017; Zhao \& Llosa, 2008; Zhao, 2017, 2019) or calculating usage frequency (Tang \& John, 1999; Wu \& Rubin, 2000; Hyland \& Milton, 1997; Palacas, 1989; Barton, 1995). However, such practice overlooked the complex interaction between the personal and the social dimensions of voice and they failed to realize that textual features are not voice, but a part that contributes to the author's voice construction. Particular textual features reflect the author's voice and formulate a voice effect, which could be exemplified by Liu's voice construction process. Liu hoped to arouse the readers' thinking over the choices of life after their reading of her story. That was the author's voice. To deliver her voice, Liu chose to use the first person voice and build up a character that faced a choice between fun and study after a series of experiences. Liu didn't make a decision for her character, but left it to her readers, so as to inspire their thinking over this question. In the end, it could be observed that Liu delivered a rather good voice effect through her text. However, before this, the voice effect in Liu's previous drafts was not so satisfactory, during which Liu was caught in a dilemma between the real and the fictive. Using the third person voice made her constantly attach herself to her character, resulting in flatness and dullness of particular character and further leading to less effective presentation of her voice. Such pleasing change didn't solely owe to the author's effort, but a co-constructed result by the author and the readers, which could be observed through the analysis of voice based on Canagarajah's (2014) analytical framework.

Although this study only focused on the four components from the writer's perspective due to limited space, it still revealed the complexity, dynamism and dialogicality of the process of voice construction to some degree. At first, Liu faced with trouble of detaching herself from her story and formulated an unsatisfactory voice effect through her story. Factors of identity were the major source of her struggle: the life experience was her story material, which confused her between the real and the fictive; writing experience in argumentative writing made her accustomed to reasoning and telling, and difficulties of transferring from Chinese to English hindered her expression, both of which lessened the voice effect she tried to convey. However, in face with the conflicts between personal history and the role of student writer, influenced by different discourses (i.e. teacher feedback, student feedback and input readings), through rounds of dialogue with all these constructs, Liu finally found a way out of the struggle, gradually made her voice discernible and successfully constructed a relatively satisfactory voice effect through the text. It was a co-constructing process during which the writer played the autonomy. In this process, Liu changed from confusion to awareness of the problems and the solutions, knowing to deliver her voice through genre knowledge and text. Furthermore, the writing process prompted her to deepen her thinking and understanding over life. It could be seen that voice is not prescriptive or immutable. It may change dynamically under its construction in a dialogic manner, which is a complicated process beyond text.

Although only one participant was reported in this article, this study had its empirical and pedagogical meaning. For one thing, it enriches studies of voice from the dialogic perspective, especially in Chinese context where study of voice was still a young field (Zhang, Chen \& Wang 2019). For another, it is a new exploration to short story writing from the perspective of voice. This study revealed the complexity of voice construction in short story writing. Through constant negotiation and rounds of dialogue, the student writer enabled to walk out of struggle and completed a rather satisfactory work. In the negotiating process, some writing problems of the student writer and the reasons hidden behind could be dissected with the help of Canagarajah's (2014) analytical framework of voice, which could help to learn more about EFL learners' writing process and be beneficial to the teaching of short stories. Furthermore, such negotiated pedagogy was proved, at least by the present study, to be helpful to assist EFL learners to express themselves in English.

\section{Conclusion}

This article has discussed the textual features that present the author's voice and the complexity of EFL learners' voice construction in short story writing based on Canagarajah's (2014) analytical framework of voice. This study has identified that the narrative voice, the plot structure and the character were major features that the writer used to deliver her voice. It has shown that the construction of voice is a complicated, dynamic and dialogic process. The conflict between the identity and the role resulted in the student writer's struggle between her real experience and her fictional story. However, the student writer showed her autonomy among such discourses as teacher feedback, student feedback and input readings and finally developed a rather good awareness of expressing herself through writing. Overall, these findings enhance our understanding of EFL learners' voice construction in short story writing and also contribute to the instruction of writing in English to 
express the mind. The major limitation of the study is the paucity of information from the reader's perspective. Further study could research the voice construction with the components of identity, role, subjectivity and awareness from this perspective. Moreover, more descriptive research is needed to explore the complexity of voice construction for better understanding of voice in dialogic view.

\section{References}

Atkinson, D. (1999). Individualism and the Teaching of Writing: Response to Vai Ramanathan and. Journal of Second Language Writing, 8(3), 327-338. https://doi.org/10.1016/S1060-3743(99)80120-9

Atkinson, D. (2001) Reflections and refractions on the JSLW special issue on voice. Journal of Second Language Writing, 10(1-2), 107-124. https://doi.org/10.1016/S1060-3743(01)00035-2

Barton, E. L. (1995). Contrastive and non-contrastive connectives: Metadiscourse functions in argumentation. Written Communication, 2, 219-239. https://doi.org/10.1177/0741088395012002003

Butt, D., Fahey, R., Feez, S., Spinks, S., \& Yallop, C. (2003) Using functional grammar: An explorer's guide (2nd ed.). Sydney: National Centre for English Language Teaching and Research, Macquarie University.

Camps, D., \& Ivanič, R. (2001). I am how I sound Voice as self-representation in L2 writing. Journal of Second Language Writing, 10, 3-33. https://doi.org/10.1016/S1060-3743(01)00034-0

Canagarajah, A. S. (2014). "Blessed in my own way:" Pedagogical affordances for dialogical voice construction in multilingual student writing. Journal of Second Language Writing, 27, 122-139. https://doi.org/10.1016/j.jslw.2014.09.001

Dressen-Hammouda, D. (2008). From novice to disciplinary expert: Disciplinary identity and genre mastery. English for Specific Purposes, 27(2), 233-252. https://doi.org/10.1016/j.esp.2007.07.006

Dressen-Hammouda, D. (2014). Measuring the voice of disciplinarity in scientific writing: A longitudinal exploration of experienced writers in geology. English for Specific Purposes, 34(1), 14-25. https://doi.org/10.1016/j.esp.2013.10.001

Elbow, P. (1999). Individualism and the teaching of writing: Response to Vai Ramanathan and Dwight Atkinson. Journal of Second Language Writing, 8(3), 327-338. https://doi.org/10.1016/S1060-3743(99)80120-9

Helms-Park, R., \& Stapleton, P. (2003). Questioning the importance of individualized voice in undergraduate L2 argumentative writing: An empirical study with pedagogical implications. Journal of Second Language Writing, 12(3), 245-265. https://doi.org/10.1016/j.jslw.2003.08.001

Hirvela, A., \& Belcher, D. (2002). Coming back to voice. Journal of Second Language Writing, 10(1-2), 83-106. https://doi.org/10.1016/s1060-3743(00)00038-2

Hyland, K., \& Milton, J. (1997). Hedging in L1 and L2 student writing. Journal of Second Language Writing, 2, 183-206. https://doi.org/10.1016/S1060-3743(97)90033-3

Jeffery, J. V. (2011). Subjectivity, intentionality and manufactured moves: Teachers' perceptions of voice in the evaluation of secondary students' writing. Research in the Teaching of English, 46(1), 92-127.

Matsuda, P. K. (2001). Voice in Japanese written discourse: Implications for second language writing. Journal of Second Language Writing, (1-2), 35-53. https://doi.org/10.1016/S1060-3743(00)00036-9

Matsuda, P. K. (2015). Identity in written discourse. Annual Review of Applied Linguistics, 35(August), 140-159. https://doi.org/10.1017/S0267190514000178

Matsuda, P. K., \& Tardy, C. M. (2007). Voice in academic writing: The rhetorical construction of author identity in blind manuscript review. English for Specific Purposes, 26(2), 235-249. https://doi.org/10.1016/ j.esp.2006.10.001

Matsuda, P. K., \& Tardy, C. M. (2008). Continuing the conversation on voice in academic writing. English for Specific Purposes, 27(1), 100-105. https://doi.org/10.1016/j.esp.2007.04.002

Morton, J., \& Storch, N. (2019). Developing an authorial voice in PhD multilingual student writing: The reader's perspective. Journal of Second Language Writing, 43(February 2018), 15-23. https://doi.org/10.1016/j.jslw. 2018.02.004

Palacas, A. (1989). Parentheticals and personal voice. Written Communication, 4, 506-527. https://doi.org/ $10.1177 / 0741088389006004005$

Peng, Y. J., \& Xu, F. (2018). Eryu xiezuo shengyin de sange zhengyixing wenti (Three disputed questions in 
voice of second language writing). Waiyujie (Foreign Language World), 4, 76-84.

Prior, P. (2001). Voices in text, mind, and society: Sociohistoric accounts of discourse acquisition and use. Journal of Second Language Writing, 10, 55-81. https://doi.org/10.1016/S1060-3743(00)00037-0

Ramanathan, V., \& Atkinson, D. (1999). Individualism, academic writing, and ESL writers. Journal of Second Language Writing, 8(1), 45-75. https://doi.org/10.1016/S1060-3743(99)80112-X

Stapleton, P., \& Helms-Park, R. (2008). A response to Matsuda and Tardy's "Voice in academic writing: The rhetorical construction of author identity in blind manuscript review." English for Specific Purposes, 27(1), 94-99. https://doi.org/10.1016/j.esp.2007.04.001

Stock, I., \& Eik-Nes, N. L. (2016). Voice features in academic texts - A review of empirical studies. Journal of English for Academic Purposes, 24, 89-99. https://doi.org/10.1016/j.jeap.2015.12.006

Tang, R., \& John, S. (1999). The "I" in identity: Exploring writer identity in student academic writing through the first person pronoun. English for Specific Purposes, 18, S23-S39. https://doi.org/10.1016/ S0889-4906(99)00009-5

Tardy, C. M. (2012b). Voice construction, assessment, and extra-textual identity. Research in the Teaching of English, 47(1), 64-99.

Tardy, C. M. (2012a). Current Conceptions of Voice. In K. Hyland, \& C. Sancho-Guinda (Eds.), Stance and Voice in Written Academic Genres (pp. 34-49). Basingstoke: Palgrave Macmillan. https://doi.org/10.1057/ 9781137030825_3

Tardy, C. M. (2015). Voice and Identity. In Handbook of Second and Foreign Language Writing, edited by Rosa M. Manchon and Paul Matsuda. New York: Walter de Gruyter. https://doi.org/10.1515/9781614511335-019

Wong, V. F., \& Lim, J. M. H. (2014). Linking communicative functions with linguistic resources in short stories: Implications of a narrative analysis for second language writing instruction. System, 45(1), 147-162. https://doi.org/10.1016/j.system.2014.05.008

Wu, S. Y., \& Rubin, D. L. (2000). Evaluating the impact of collectivism and individualism on argumentative writing by Chinese and North American college students. Research in the Teaching of English, 35(2), 148-178.

Yancey, K. B. (1994). Voices on voice: Perspectives, definitions, inquiry. Urbana, IL: NCTE

Yoon, H. J. (2017). Textual voice elements and voice strength in EFL argumentative writing. Assessing Writing, 32, 72-84. https://doi.org/10.1016/j.asw.2017.02.002

Zhang, C., Chen, Y., \& Wang, J. (2019). The underrepresented sibling of the Symposium on Second Language Writing-A report from Mainland China. Journal of Second Language Writing, 44(February), 117-122. https://doi.org/10.1016/j.jslw.2019.03.006

Zhao, C. G., \& Llosa, L. (2008). Voice in high-stakes L1 academic writing assessment: Implications for L2 writing instruction. Assessing Writing, 13(3), 153-170. https://doi.org/10.1016/j.asw.2008.10.003

Zhao C. G. (2013) Guowai xiezuo shengyin yanjiu: huigu fenxi yu qishi (Studies of voice in writing abroadreview, analysis and instruction). Waiyujie (Foreign Language World) 3, 67-76

Zhao, C. G. (2017). Voice in timed L2 argumentative essay writing. Assessing Writing, 31, 73-83. https://doi.org/10.1016/j.asw.2016.08.004

Zhao, C. G. (2019). Writer background and voice construction in L2 writing. Journal of English for Academic Purposes, 37, 117-126. https://doi.org/10.1016/j.jeap.2018.11.004

\section{Copyrights}

Copyright for this article is retained by the author(s), with first publication rights granted to the journal.

This is an open-access article distributed under the terms and conditions of the Creative Commons Attribution license (http://creativecommons.org/licenses/by/4.0/). 